\title{
Bibliotber Der
}

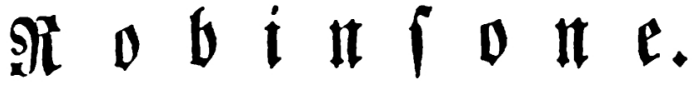

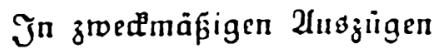

bom

Derfafier der grauen Milappe.

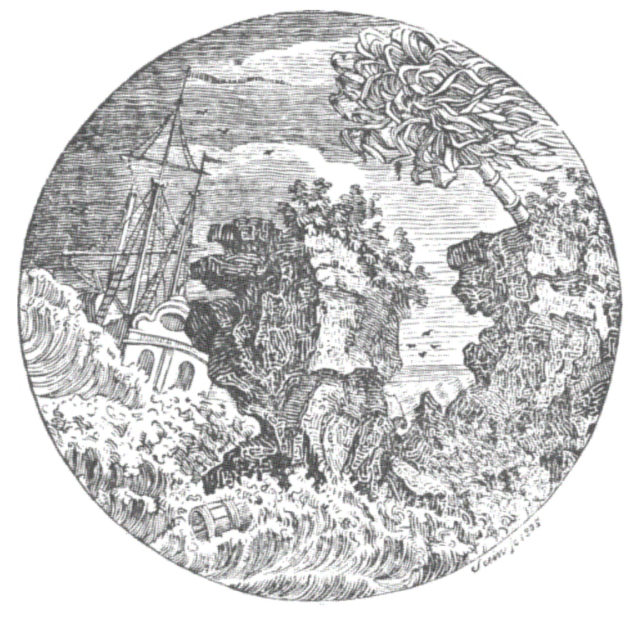

'Dritfer $\mathfrak{B}$ and.

V̌erlin, 1806.

23ei Jobann Txries:i f $11 \pi$ ger. 
